\title{
Chemical composition and biological activities of essential oils of Foeniculum vulgare Mill. and Daucus carota L. growing wild in Turkey
}

\author{
Hüseyin SERVİ 1 * (D), Ali ŞEN 2 (D), Esra YILDIRIM SERVİ 3 (D), Ahmet DOĞAN 4 (D) \\ 1 Department of Pharmacognosy, Faculty of Pharmacy, İstanbul Yeni Yüzyıl University, İstanbul, Turkey. \\ 2 Department of Pharmacognosy, Faculty of Pharmacy, Marmara University, İstanbul, Turkey. \\ 3 Halal Food and R\&D Center, İstanbul Sabahattin Zaim University, İstanbul, Turkey. \\ 4 Department of Pharmaceutical Botany, Faculty of Pharmacy, Marmara University, İstanbul, Turkey. \\ * Corresponding Author. E-mail: servi@hotmail.com.tr (H.S.); Tel. +90-543-649 5413.
}

Received: 16 December 2020 / Revised: 27 January 2021 / Accepted: 09 February 2021

\begin{abstract}
The chemical composition of essential oils of aerial parts of Daucus carota (DEO) and Foeniculum vulgare (FEO) was specified by GC/MS. Antidiabetic, anti-inflammatory, antioxidant, and antibacterial activities of oils were tested by $\alpha$-glucosidase inhibitory, 5-lipoxygenase inhibitory, DPPH/ABTS radical scavenging, and broth microdilution methods, respectively. Thirty components were identified in DEO (87.7\%). Carotol (27.7\%), elemicin (18.1\%), and limonene $(16.0 \%)$ were determined as the main compounds in DEO. Seventeen constituents were identified in FEO $(100.0 \%)$. Estragole $(34.0 \%)$, limonene $(27.1 \%)$, and $\alpha$-pinene $(19.5 \%)$ were found as major components in FEO. Both oils displayed weak antibacterial activity against Gram-negative bacteria. However, the oils were not effective on Grampositive bacteria. DEO with $\mathrm{IC}_{50}$ values of 1359 and $1579 \mu \mathrm{g} / \mathrm{mL}$ and FEO with $\mathrm{IC}_{50}$ values of $3106 \mathrm{and} 1654 \mu \mathrm{g} / \mathrm{mL}$ showed weak antioxidant activities against DPPH and ABTS radicals, respectively. DEO and FEO exhibited good antilipoxygenase activities with $\mathrm{IC}_{50}$ values of 87.24 and $58.35 \mu \mathrm{g} / \mathrm{mL}$, respectively. DEO presented significantly $\alpha$ glucosidase inhibitory activity with an $\mathrm{IC}_{50}$ value of $44.78 \mu \mathrm{g} / \mathrm{mL}$ while FEO displayed poor activity with an $\mathrm{IC}_{50}$ value of $1967 \mu \mathrm{g} / \mathrm{mL}$. This study is the first report on the 5-lipoxygenase and $\alpha$-glucosidase inhibitory activities of aerial parts of DEO as well as on the $\alpha$-glucosidase inhibitory activity of aerial parts of FEO. These results indicated that DEO, which has a good antidiabetic and anti-inflammatory activity, is rich in oxygenated sesquiterpene and monoterpene. Also, it showed that FEO, which has a significant anti-inflammatory activity, is rich in monoterpene and phenylpropanoid.
\end{abstract}

KEYWORDS: Daucus carota; Foeniculum vulgare; essential oils; biological activity.

\section{INTRODUCTION}

Foeniculum vulgare Mill. (Fennel) and Daucus carota L. (Wild carrot) are members of Apiaceae family. Fennel is a perennial herbaceous plant and grows 1-1.8 m. The flowers of the fennel are18-25 per umbellule and have yellow petals. The fruits of the fennel are ovoid-oblong-shaped, glabrous, and with prominent ridges. Fennel is spread mainly in West, South, and Central Europe, South-West Asia, and North Africa [1]. F. vulgare is called 'Rezene and Arapsaç' in Anatolia used for the treatment of stomach discomfort, digestive facilitator, relieve gas, stomach and abdominal pains, against diarrhea and intestinal worms, colds, cough, chest softener, expectorant, kidney stone, urine enhancer, sedative, insomnia, eye itching, and milk secretion enhancer [2] due to its hepatoprotective effect, antioxidant, antithrombotic, anti-inflammatory, antidiabetic, antitumor, acaricidal, antifungal and antibacterial activities [3-4]. Fennel is a fragrance and delicious plant with culinary and therapeutic uses. The plant oils have a typical anise scent. The fennel oil had trans-anethole, fenchone, estragole (methyl chavicol), and $\alpha$-phellandrene as the main components [3-5].

Wild carrot is a biennial plant and grows $10-200 \mathrm{~cm}$. The flowers of wild carrot are white, pinkish, or yellowish petals [1]. The plant is a vegetable utilized in human alimentation. It is native to Europe, Asia, and Africa. D. carota is named 'Havuç, havuç tohumu, yere geçen, keşür and pörçüklü' [6] in Anatolia is used for the treatment of diabetes, eye diseases, skin disorders, constipation, against intestinal worms and

How to cite this article: Servi H, Şen A, Yıldırım Servi E, Doğan A. Chemical composition and biological activities of essential oils of Foeniculum vulgare Mill. and Daucus carota L. growing wild in Turkey. J Res Pharm. 2021; 25(2): 142-152. 
hemorrhoids, getter, digestive facilitator, breast softener [2] due to antibacterial, antifungal, anthelmintic, hepatoprotective and cytotoxic activities [7]. The wild carrot oil is utilized as a diuretic and stomachic. The wild carrot oil has biological properties such as antimicrobial, hepatocellular regenerator, general tonic and stimulant, cholesterol regulatör, and cicatrizant [6]. The main compounds of oils of D. carota were carotol, sabinene, $\alpha$-pinene, geraniol, $\beta$-bisabolene, $\gamma$-bisabolene, $(E)$-methyl isoeugenol, $(E)$-asorene, daucene and geranyl acetate $[6,8]$. There are many reports on the essential oil composition of $D$. carota and F. vulgare in the literature. However, there are no reports on the essential oil composition of D. carota growing wild in Turkey. Also, this study is the first report on the 5-lipoxygenase and $\alpha$-glucosidase inhibitory activities of aerial parts of DEO as well as on the $\alpha$-glucosidase inhibitory activty of aerial parts of FEO. This study aimed to specify the biological activities of the essential oils of $D$. carota and F. vulgare.

\section{RESULTS}

The yields of DEO and FEO were 0.88 and $0.77 \%(\mathrm{v} / \mathrm{w})$, respectively. Thirty components were identified in DEO (87.7\%). Carotol (27.7\%), elemicin $(18.1 \%)$, and limonene $(16.0 \%)$ were determined as the main compounds in DEO (Figure 1 and Table 1). The dominant groups of DEO were oxygenated sesquiterpenes (32.4\%), monoterpene (26.9\%), and phenylpropanoid (18.5\%) (Table 1). Seventeen constituents were identified in FEO (100.0\%). Estragole (34.0\%), limonene (27.1\%), and $\alpha$-pinene $(19.5 \%)$ were found as major components in FEO (Figure 2 and Table 1). FEO had monoterpene (56.6\%) and phenylpropanoid (34.0\%) as major groups (Table 1). DEO and FEO displayed weak antibacterial activity against Gram-negative bacteria. However, the oils were not effective on Gram-positive bacteria (Table 2).

DEO and FEO showed poor DPPH radical scavenging activity with $\mathrm{IC}_{50}$ values of 1359 and $3106 \mu \mathrm{g} / \mathrm{mL}$ compared to the $\mathrm{IC}_{50}$ value of standard ascorbic acid, $17.60 \mu \mathrm{g} / \mathrm{mL}$. Also, DEO and FEO showed low ABTS radical scavenging activity with $\mathrm{IC}_{50}$ values of 1579 and $1654 \mu \mathrm{g} / \mathrm{mL}$ compared to the $\mathrm{IC}_{50}$ value of standard ascorbic acid, $13.00 \mu \mathrm{g} / \mathrm{mL}$ (Table 3). DEO and FEO with $\mathrm{IC}_{50}$ values of 87.24 and $58.35 \mu \mathrm{g} / \mathrm{mL}$ displayed good anti-lipoxygenase activity compared to standard indomethacin with an $\mathrm{IC}_{50}$ value of $22.39 \mu \mathrm{g} / \mathrm{mL}$, respectively (Table 3). DEO and FEO presented significant and weak $\alpha$-glucosidase inhibitory activity with $\mathrm{IC}_{50}$ values of 44.78 and $1967.00 \mu \mathrm{g} / \mathrm{mL}$ compared with that of acarbose $(40.06 \mu \mathrm{g} / \mathrm{mL})$, respectively (Table 3 ).

\section{DISCUSSION}

The essential oil of $F$. vulgare possessed remarkable diversities in the main compounds. These diversities could be related to morphological characteristics and different geographical origins. Estragole, fenchone, and limonene were determined as main compounds in the volatile oil of F. vulgare growing wild in Turkey [9-11]. Fenchone is utilized as a counter-irritant and found a low amount in the oil of the current report, $\alpha$-pinene is used as insecticides, solvents, and perfume bases [12]. This compound was determined in a low amount (1.0$1.5 \%$ ) in the previous reports [9-11]. The essential oil of cultivated F. vulgare of Turkish origin possessed transanethole as the main compound [13-18]. However, this compound was not determined in the oil of the present study. The absence of trans-anethole in the present study together with the low content of $\alpha$-pinene in previous studies suggests these differences are observed due to different chemovarieties of the plant. In the present report, the volatile oil of aerial parts of $F$. vulgare showed a similar chemical profile with $F$. vulgare growing wild in Turkey but there are quantitative differences in the major components of essential oils.

The chemical composition of essential oils of $D$. carota showed variations during ontogenesis. Especially, the phenylpropanoid contents are found in high amounts in the mature umbels [19]. Carotol was determined as the main compound in the essential oil of cultivated D. carota from Turkey. Also, limonene was found in a low amount $(0.4 \%)$ and elemicin was not detected in the oil of the previous study [20]. The present study showed that have similar essential oil components to previous studies. However, there are quantitative dissimilarities in the major components of the oils. 
Abundance

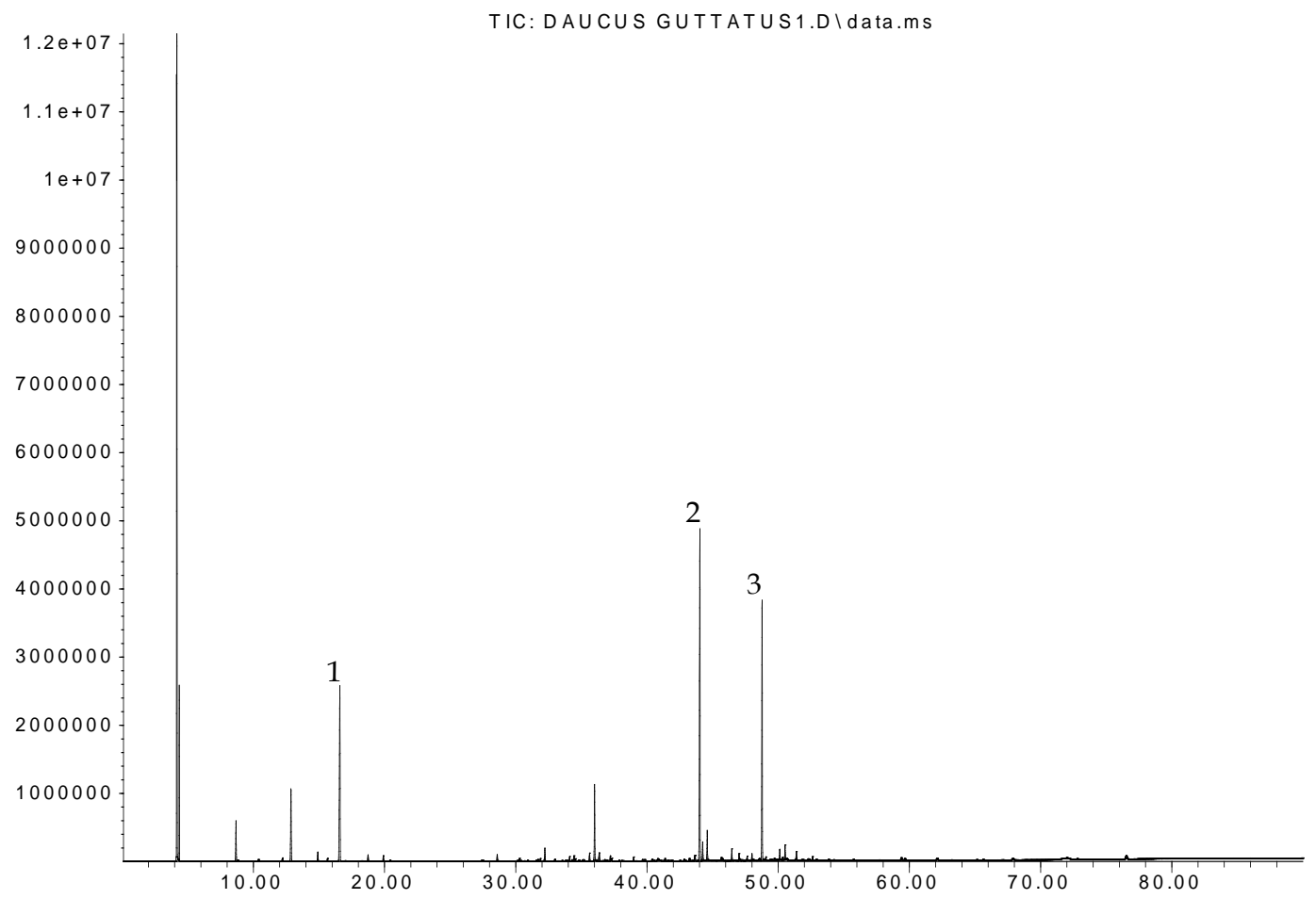

Time-->

Figure 1. GC-MS chromatogram of DEO (1: Limonene; 2: Carotol; 3: Elemicine).

Abundance

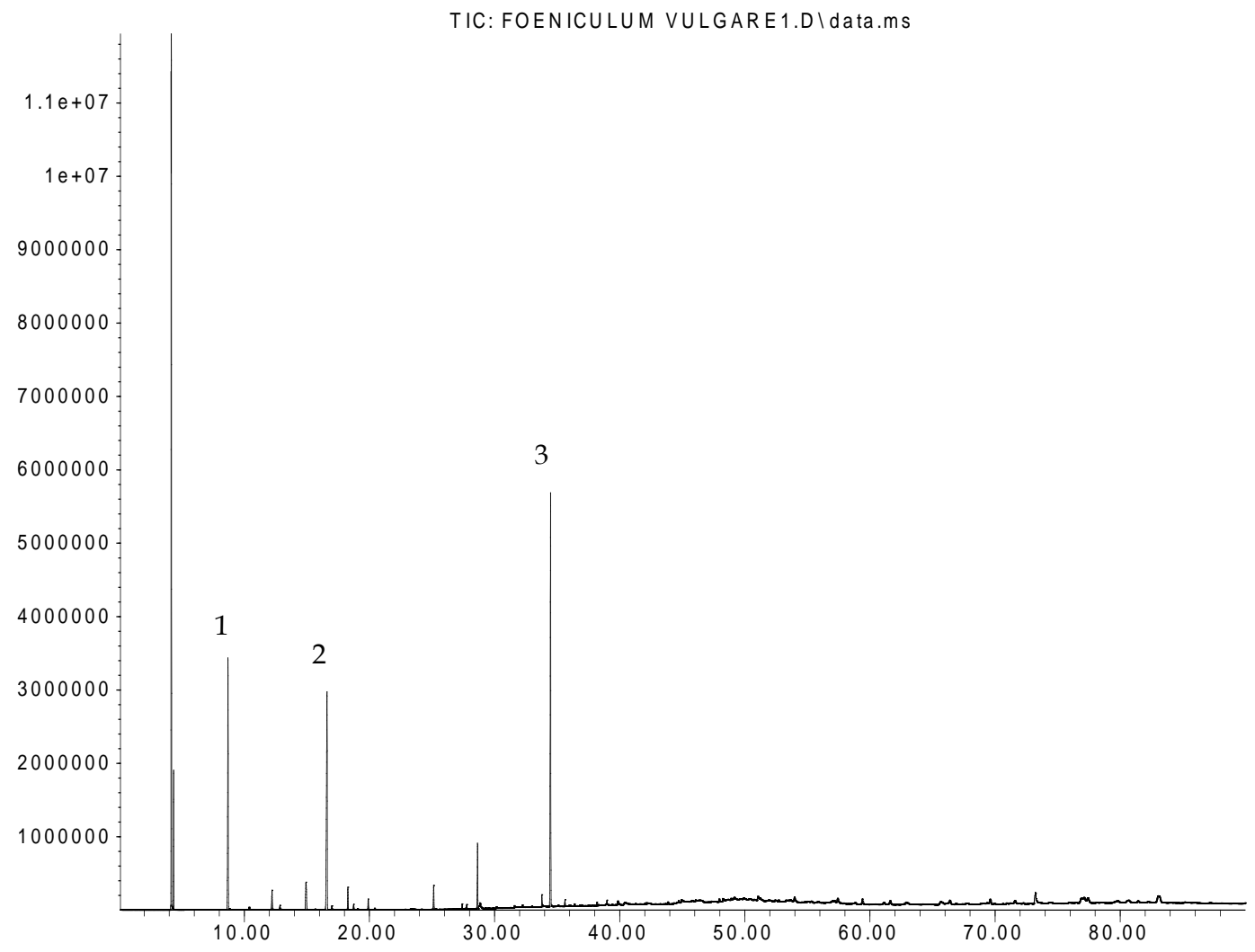

Time-->

Figure 2. GC-MS chromatogram of FEO (1: $\alpha$-pinene; 2: Limonene; 3: Estragole). 
Table 1. The essential oil composition of aerial parts of Daucus carota and Foeniculum vulgare.

\begin{tabular}{|c|c|c|c|c|}
\hline RRI $^{1}$ & RRI Lit. ${ }^{2}$ & Compounds & D. carota $(\%)$ & F. vulgare (\%) \\
\hline 1020 & 1032 & $\alpha$-Pinene & 2.8 & 19.5 \\
\hline 1064 & 1076 & Camphene & 0.2 & - \\
\hline 1109 & 1118 & $\beta$-pinene & 0.3 & 1.9 \\
\hline 1123 & 1132 & Sabinene & 5.8 & 0.4 \\
\hline 1165 & 1174 & Myrcene & 0.7 & - \\
\hline 1166 & 1176 & $\alpha$-Phellandrene & - & 3.8 \\
\hline 1181 & 1188 & $\alpha$-Terpinene & 0.2 & - \\
\hline 1200 & 1203 & Limonene & 16.0 & 27.1 \\
\hline 1209 & 1218 & $\beta$-Phellandrene & - & 0.4 \\
\hline 1237 & 1246 & $\beta$-(Z)-Ocimene & - & 2.0 \\
\hline 1248 & 1255 & $\gamma$-Terpinene & 0.5 & 0.5 \\
\hline 1274 & 1278 & $p$-Cymene & 0.4 & 1.0 \\
\hline 1400 & 1406 & Fenchone & - & 2.0 \\
\hline 1463 & 1468 & Trans-limonene oxide & - & 0.4 \\
\hline 1474 & 1482 & $\alpha$-Fencyl acetate & - & 0.4 \\
\hline 1548 & 1553 & $\beta$-linalool & 0.2 & - \\
\hline 1590 & 1594 & Trans- $\alpha$-bergamotene & 0.1 & - \\
\hline 1596 & 1600 & $\beta$-Elemene & 0.2 & - \\
\hline 1597 & 1591 & Fencyl alcohol & - & 5.1 \\
\hline 1607 & 1607 & Terpinen-4-ol & 1.0 & - \\
\hline 1632 & 1639 & Trans-p-mentha-2,8-dienol & 0.1 & - \\
\hline 1669 & 1668 & (Z)- $\beta$-Farnesene & 0.3 & - \\
\hline 1680 & 1687 & Estragole & 0.4 & 34.0 \\
\hline 1684 & 1683 & Trans-verbenol & 0.2 & - \\
\hline 1720 & 1726 & Germacrene D & 0.6 & 0.5 \\
\hline 1734 & 1737 & $\beta$-Bisabolene & 5.4 & - \\
\hline 1746 & 1751 & Carvone & 0.9 & - \\
\hline 1780 & 1784 & $\alpha$-Bisabolene & 0.2 & - \\
\hline 1840 & 1845 & Trans-carveol & 0.3 & 0.4 \\
\hline 2020 & 2050 & $(E)$-Nerolidol & 0.7 & - \\
\hline 2036 & 2045 & Carotol & 27.7 & - \\
\hline 2137 & 2144 & Spathulenol & 0.9 & - \\
\hline 2237 & 2245 & Elemicine & 18.1 & - \\
\hline 2297 & 2284 & Daucol & 0.9 & - \\
\hline 2314 & 2313 & Juniper camphor & 1.3 & - \\
\hline 2350 & 2369 & $(2 E, 6 E)$-Farnesol & 0.9 & - \\
\hline \multirow[t]{8}{*}{2613} & 2622 & Phytol & 0.4 & 0.6 \\
\hline & & Monoterpenes & 26.9 & 56.6 \\
\hline & & Oxygenated Monoterpenes & 2.7 & 8.3 \\
\hline & & Sesquiterpenes & 6.8 & 0.5 \\
\hline & & Oxygenated Sesquiterpenes & 32.4 & - \\
\hline & & Diterpenes & 0.4 & 0.6 \\
\hline & & Phenylpropanoid & 18.5 & 34.0 \\
\hline & & Total identified compounds & 87.7 & 100.0 \\
\hline
\end{tabular}

${ }^{1}$ RRI: Relative retention time;

2RRI Lit: Relative retention index of the compound given in the literature.

Table 2. Antibacterial activity of essential oils of Daucus carota and Foeniculum vulgare.

\begin{tabular}{lcccc}
\hline \multirow{2}{*}{ Essential oils } & \multicolumn{2}{c}{ Gram-positive bacteria } & \multicolumn{2}{c}{ Gram-negative bacteria } \\
\cline { 2 - 4 } & $\begin{array}{c}\text { Staphylococcus } \\
\text { aureus }\end{array}$ & Bacillus subtilis & $\begin{array}{c}\text { Klebsiella } \\
\text { pneumoniae }\end{array}$ & Escherichia coli \\
\cline { 2 - 4 } D. carota & $>18 \mathrm{mg} / \mathrm{mL}$ & $>18 \mathrm{mg} / \mathrm{mL}$ & $18 \mathrm{mg} / \mathrm{mL}$ & $18 \mathrm{mg} / \mathrm{mL}$ \\
F. vulgare & $>18 \mathrm{mg} / \mathrm{mL}$ & $>18 \mathrm{mg} / \mathrm{mL}$ & $9 \mathrm{mg} / \mathrm{mL}$ & $18 \mathrm{mg} / \mathrm{mL}$ \\
\hline
\end{tabular}


Table 3. Antioxidant, anti-inflammatory, and antidiabetic activities of DEO and FEO.

\begin{tabular}{lcccc}
\hline & \multicolumn{2}{c}{ Antioxidant activity } & $\begin{array}{c}\text { Anti-inflammatory } \\
\text { activity }\end{array}$ & Antidiabetic activity \\
\cline { 2 - 5 } $\begin{array}{c}\text { Essential oils } \\
\text { and standards }\end{array}$ & $\begin{array}{c}\text { DPPH radical } \\
\text { scavenging } \\
\text { activity }\end{array}$ & $\begin{array}{c}\text { ABTS radical } \\
\text { scavenging } \\
\text { activity }\end{array}$ & $\begin{array}{c}\text { Anti-lipoxygenase } \\
\text { activity }\end{array}$ & $\begin{array}{c}\alpha \text {-glucosidase } \\
\text { inhibitory activity }\end{array}$ \\
\cline { 2 - 5 } & & $1579 \pm 1.41^{\mathrm{b}}$ & $\mathbf{I C}_{50}(\boldsymbol{\mu g} / \mathbf{m L})$ & \\
$n$ & $1359 \pm 7.07^{\mathrm{b}}$ & $87.24 \pm 4.34^{\mathrm{c}}$ & $44.78 \pm 0.31^{\mathrm{a}}$ \\
FEO $^{*}$ & $3106 \pm 9.19 \mathrm{c}$ & $1654 \pm 2.83 \mathrm{c}$ & $58.35 \pm 0.92^{\mathrm{b}}$ & $1967.00 \pm 7.07^{\mathrm{b}}$
\end{tabular}

Ascorbic acid $\quad 17.60 \pm 0.37$ a

Trolox $\quad 13.00 \pm 0.21^{\text {a }}$

Indomethacin $\quad 22.39 \pm 0.26^{a}$

Acarbose

$40.06 \pm 2.14^{\mathrm{a}}$

*Abbreviations: DEO and FEO show essential oils obtained from aerial parts of Daucus carota and Foeniculum vulgare, respectively. ${ }^{* *}$ Each value in the table is represented as mean $\pm \mathrm{SD}(n=3)$. Different letter superscripts in the same column indicate significantlydifferences $(p<0.05)$.

(E)-Methyl isoeugenol, $\alpha$-pinene, elemicin, carotol, sabinene, limonene, $\beta$-pinene, myrcene, $11 \alpha-\mathrm{H}$ himachal-4-en-1 $\beta$-ol, $\beta$-bisabolene, geranyl acetate, trans-anethole, $(E)-\beta$-ocimene, caryophyllene, epibicyclosesquiphaellandrene, terpinen-4-ol, shyobunone, $\beta$-cubebene, preisocalamendiol, isoelemicin, and myristicin were determined as main compounds in the oils of D. carota of other geographical origins [19-47]. The similarities and dissimilarities were observed between essential oil constituents of the present and previous studies. (E)-methyl isoeugenol, $11 \alpha$-H-himachal-4-en- $1 \beta$-ol, geranyl acetate, trans-anethole, $(E)-\beta$ ocimene, caryophyllene, epi-bicyclosesquiphaellandrene, shyobunone, $\beta$-cubebene, preisocalamendiol, isoelemicin, and myristicin were not determined in the oil of the present study. The previous researches specified that $D$. carota had monoterpene, oxygenated monoterpene, sesquiterpene, oxygenated sesquiterpene, and phenylpropanoid as dominant groups. In the present report, the oil of aerial parts of $D$. carota showed that have similar dominant groups with the previous researches.

The variations of essential oil ingredients and composition may be connected to factors such as plant parts used, geographical regions, genotype, ecotype, chemotype, phenophases, and the environment. The environmental factors can be temperature, relative humidity, irradiance, and photoperiod. The quantitative composition of the volatile oils of numerous aromatic plants is significantly influenced by the harvesting time, plant age, and product density [48].

In studies conducted by Staniszewska et al. (2005) and Jabrane et al. (2009) determined that D. carota oil was effective on Gram-positive and Gram-negative bacteria [42,46]. In another study, Glišić et al. (2007) and Asilbekova et al. (2017) reported that D. carota essential oil showed strong activity against Gram-positive bacteria but was not effective on Gram-negative bacteria [43,47]. The results of the current study did not support the literature. The previous studies had monoterpene and oxygenated sesquiterpene as dominant groups. They did not include the phenylpropanoid group as a high amount as with the present study. The results of the current study might be due to the synergistic activity of the phenylpropanoid group and other major groups present in the oil. Diao et al. (2014), Gulfraz et al. (2008), Anwar et al. (2009), Roby et al. (2012), Dadalioglu and Evrendilek (2004) reported that F. vulgare essential oil was effective on Gram-positive and Gram-negative bacteria at different MIC values [3,49-52]. The results of the current study did not support the literature. Trans-anethole was the main compound in the oil of previous studies. This compound was not detected in the oil of the current study. The antimicrobial activity of six essential oils of F. vulgare fruits from different locations of Portuguese was studied. Fenchone, estragole, and trans-anethole were determined as the main compounds in different percentages. Limonene and $\alpha$-pinene were found in a low amount in estragole chemotype oils. And estragole chemotype oils were effective on Gram-positive and Gram-negative bacteria at different MIC values [53]. The antibacterial activity results of the current study showed a dissimilar profile from the previous study. This dissimilar profile could be related to the different percentages of the main compounds in the oils.

In a study conducted by Meliani et al. (2012), it was found that hydro-distilled essential oil obtained from the aerial parts of Daucus carota subsp. carota had weak antioxidant activity against DPPH radical with $\mathrm{IC}_{50}$ value of $40.97 \mathrm{mg} / \mathrm{mL}$ [28]. In another study, Mohammedi et al. (2015) reported that essential oils of $D$. carota subsp. carota aerial parts before flowering and after flowering had a low antioxidant activity with $\mathrm{IC}_{50}$ values $>200 \mu \mathrm{g} / \mathrm{mL}$. In the same study, it was found that the essential oil of $D$. carota subsp. carota aerial parts 
in full flowering had a good activity with an $\mathrm{IC}_{50}$ value of $96.4 \mu \mathrm{g} / \mathrm{mL}$ against the DPPH radical [54]. Except for the last report, the results of previous studies are in line with the results of our current study. Felice et al. showed that essential oil of F. vulgare Mill. subsp. vulgare var. azoricum leaves had a weak antioxidant capacity against DPPH free radical [55]. In another study, it was found that all essential oils from dried aerial parts $F$. vulgare with different hydrodistillation times had low DPPH radical scavenging activity with an inhibition rate below $40 \%$ at the concentration of $1000 \mu \mathrm{g} / \mathrm{mL}$ [56]. Also, Albano et al. reported that the essential oil of Foeniculum vulgare aerial part had an $\mathrm{IC}_{50}$ value of $2342.0 \mu \mathrm{g} / \mathrm{mL}$ against DPPH radical [57]. These studies support the results of our current study.

Albano et al. indicated that essential oil of $F$. vulgare aerial part had a good anti-5-lipoxygenase activity with an $\mathrm{IC}_{50}$ value of $67.7 \mu \mathrm{g} / \mathrm{mL}$ [57]. Although there are no reports in the literature regarding the antiinflammatory activity of the essential oil obtained from the aerial part of $D$. carota by lipoxygenase inhibition method, there are studies with different methods. In one of these studies, Silva evaluated the antiinflammatory activity of the essential oil on NO release in LPS-stimulated macrophages and reported that essential oil was able to reduce by $19 \%$ the NO production in LPS-stimulated macrophages at $0.64 \mu \mathrm{L} / \mathrm{mL}$ without showing toxicity to the cells [58]. These studies also showed that both oils had significant antiinflammatory activity and were consistent with the results of our current study. Also, Frum and Viljoen revealed limonene had 5-lipoxygenase inhibitory activity [59]. Previous studies have suggested that $\alpha$-pinene [60], elemicin [61], estragole [62] had anti-inflammatory effects. Therefore, these major compounds found in DEO and FEO and other compounds may be responsible for the anti-inflammatory activities of the oils.

There is no antidiabetic activity study on DEO in the literature. However, it was reported that the ethanol extract obtained from the seeds of D. carota had antidiabetic activity [63]. Similar to DEO, there are no reports on essential oil obtained from aerial parts of F. vulgare but there are studies in the literature on the essential oil obtained from its seed. In one of these studies, El-Soude et al. evaluated the essential oil of seed of $F$. vulgare for its hypoglycaemic effect and found that the oil had good antidiabetic activity [64]. Also, previous studies have shown that limonene has antidiabetic activity [65]. Therefore, limonene and other compounds may be responsible for the activity of the essential oil obtained from DEO, which exhibits an important antidiabetic activity in our current study.

\section{CONCLUSION}

These results showed that FEO against 5-lipoxygenase and DEO against $\alpha$-glucosidase and 5lipoxygenase had good inhibitory activity. However, in vivo studies are needed to definitively determine the therapeutic efficacy of oils.

\section{MATERIALS AND METHODS}

\subsection{Plant material}

Daucus carota and F. vulgare were collected in İkitelli-Başakşehir (41 $04^{\prime} 34.9^{\prime \prime} \mathrm{N}$; $28^{\circ} 47^{\prime} 32.2^{\prime \prime}$ E), Istanbul, Turkey, in June 2017 by Huseyin Servi Ph.D and identified by Dr. Ahmet Dogan. Herbarium specimens of $D$. carota and F. vulgare were deposited in the Marmara University Herbarium (Voucher specimens numbers: MARE 22156 and MARE 20233).

\subsection{Essential oil analyses}

The aerial parts of DEO (100 g) and FEO (114 g) were subjected to hydrodistillation for $3 \mathrm{~h}$, using a Clevenger apparatus. DEO and FEO were stored in amber vials under $-20^{\circ} \mathrm{C}$ until analyzed.

\subsection{GC/MS analysis}

The GC/MS analysis and determination of essential oils components were performed as described by Servi et al. [66]. In GC/MS analyses, the Innowax FSC column ( $60 \mathrm{~m} \times 0.25 \mathrm{~mm}, 0.25 \mathrm{~m}$ film thickness) and helium as carrier gas $(1 \mathrm{~mL} / \mathrm{min})$ were used. The identification of the essential oil components was carried out by comparison of their relative retention indices obtained by series of $n$-alkanes (C 5 to C30) to the literature and with mass spectra comparison. The mass spectra comparison was done by computer matching with the 
commercial Wiley 8th Ed./NIST 05 Mass Spectra library, Adams Essential Oil Mass Spectral Library, and Pallisade 600K Complete Mass Spectra Library.

\subsection{Gas Chromatography}

The GC analyses were done with an Agilent 6890N GC system. FID detector temperature was set to $300^{\circ} \mathrm{C}$ and the same operational conditions were applied to a duplicate of the same column used in the GCMS analyses. Simultaneous autoinjection was used to obtain the same retention times. The relative percentage amounts of the separated compounds were calculated from integration of the peaks in the FID chromatograms.

\subsection{Biological activity}

\subsubsection{Antibacterial activity}

The antibacterial activity of the essential oils was evaluated against Klebsiella pneumoniae ATCC BAA1706, Escherichia coli ATCC 14169, Staphylococcus aureus ATCC 25923, and Bacillus subtilis ATCC 19659 by using a broth microdilution [67]. The stock solution of the oils $(18 \mathrm{mg} / \mathrm{mL})$ was prepared with \%10 dimethyl sulfoxide (DMSO). Serial dilution of essential oil was done on 96-well microplates using Mueller Hinton Broth (MHB). Bacteria were standardized in MHB according to McFarland No:0.5. Bacterial cultures were mixed with different concentrations of essential oils on microplates and were incubated $24 \mathrm{~h}$ at $37^{\circ} \mathrm{C}$. Minimum inhibitory concentrations (MIC: $\mathrm{mg} / \mathrm{mL}$ ) were detected at the minimum concentration where bacterial growth was not detected. Chloramphenicol was used as a positive control for assays. All the experiments were performed in duplicate.

\subsubsection{Measurement of DPPH radical scavenging activity}

The free radical scavenging activity of the essential oils, based on the scavenging activity of the stable 1,1-diphenyl-2-picrylhydrazyl (DPPH) free radical was determined by the method described by Zou et al. [68]. Briefly, $10 \mu \mathrm{L}$ of essential oils $(250-0.49 \mu \mathrm{g} / \mathrm{mL})$ or standard ascorbic acid (100-0.02 $\mu \mathrm{g} / \mathrm{mL})$ in DMSO at different concentrations were mixed with $190 \mu \mathrm{L}$ of $0.1 \mathrm{mM}$ DPPH solution in $\mathrm{MeOH}$ in a well of 96 -well plate. The reaction mixture was left in the dark at RT for $30 \mathrm{~min}$. The absorbance of the mixture was measured spectrophotometrically at $517 \mathrm{~nm}$. Each experiment was carried out in triplicate.

\subsubsection{Measurement of ABTS radical-scavenging activity}

The ABTS radical cation-scavenging activity was performed according to the method described previously [68]. ABTS radical cations were generated by mixing an equal volume of ABTS $\left(7 \mathrm{mM}\right.$ in $\left.\mathrm{H}_{2} \mathrm{O}\right)$ and potassium persulfate $\left(4.9 \mathrm{mM}\right.$ in $\left.\mathrm{H}_{2} \mathrm{O}\right)$, allowing them to react for $12-16 \mathrm{~h}$ at room temperature in the dark. ABTS radical solution was diluted with $96 \%$ ethanol to an absorbance of about 0.7 at $734 \mathrm{~nm} .10 \mu \mathrm{L}$ of essential oils $(250-0.49 \mu \mathrm{g} / \mathrm{mL})$ or standard Trolox $(100-0.02 \mu \mathrm{g} / \mathrm{mL})$ were added to $190 \mu \mathrm{L}$ of ABTS radical solution in a 96-well microplate. The reaction mixture was kept in the dark for $30 \mathrm{~min}$. Then, the absorbance was recorded at $734 \mathrm{~nm}$. All measurements were carried out in triplicate.

\subsubsection{Measurement of in vitro anti-inflammatory activity}

5-lipoxygenase inhibition activity was analyzed by the method of Phosrithong and Nuchtavorn [69] with slight modifications described by Yildırım et al. [70]. $10 \mu \mathrm{L}$ of essential oils $(250-0.49 \mu \mathrm{g} / \mathrm{mL})$ or standard indomethacin (100-0.02 $\mu \mathrm{g} / \mathrm{mL}$ ) were added to $20 \mu \mathrm{L}$ ethanol, $20 \mu \mathrm{L}$ pure water, $25 \mu \mathrm{L}$ of sodium borate buffer solution $(0.1 \mathrm{M}, \mathrm{pH}$ 9) and $25 \mu \mathrm{L}$ of type $\mathrm{V}$ soybean lipoxygenase solution in the buffer $(\mathrm{pH} 9,20.000 \mathrm{U} / \mathrm{mL})$. The reaction mixture was pre-incubated at $25^{\circ} \mathrm{C}$ for $5 \mathrm{~min}$. Then, $100 \mu \mathrm{L}$ of $0.6 \mathrm{mM}$ linoleic acid solution was added to solutions, mixed well and the change in absorbance at $234 \mathrm{~nm}$ was followed for $6 \mathrm{~min}$. Each reaction was run in triplicate.

\subsubsection{Measurement of in vitro antidiabetic activity}

The inhibition assay for $\alpha$-glucosidase activity was conducted as described by Ramakrishna et al. [71] with slight modifications described by Sen et al. [72]. In a 96-well plate, $10 \mu \mathrm{L}$ of essential oils $(250-0.49 \mu \mathrm{g} / \mathrm{mL})$ or standard acarbose $(100-0.02 \mu \mathrm{g} / \mathrm{mL}), 40 \mu \mathrm{L}$ of $0.1 \mathrm{M}$ sodium phosphate buffer (pH 6.9), and $100 \mu \mathrm{L}$ of $\alpha$ glucosidase (obtained from Saccharomyces cerevisiae) were mixed. After pre-incubation at $25^{\circ} \mathrm{C}$ for $10 \mathrm{~min}, 50$ $\mu \mathrm{L}$ of $5 \mathrm{mM} p$-nitrophenyl- $\alpha$-D-glucopyranoside (pNPG) to the solutions was added and re-incubated at $25^{\circ} \mathrm{C}$ 
for $5 \mathrm{~min}$. The absorbance reading was taken before and after incubation at $405 \mathrm{~nm}$ using a microplate reader. Tests were carried out in triplicate.

\subsection{Statistical analysis}

The data were reported as meanststandard deviations and analyzed by one-way analysis of variance (ANOVA) followed by Tukey's multiple comparison tests using GraphPad Prism 5. Differences between means at $p<0.05$ level were considered significant.

Author contributions: Concept - H.S., A.Ş.; Design - H.S., A.Ş.; Supervision - H.S., A.Ş., E.Y.S.; Resources - H.S., A.Ş., E.Y.S.; Materials - H.S., A.Ş., E.Y.S.; Data Collection and/or Processing - H.S., A.Ş., E.Y.S., A.D.; Analysis and/or Interpretation - H.S., A.Ş., E.Y.S.; Literature Search - H.S., A.Ş., E.Y.S.; Writing - H.S., A.Ş., E.Y.S., A.D.; Critical Reviews - H.S., A.Ş., E.Y.S., A.D.

Conflict of interest statement: The authors declared no conflict of interest.

\section{REFERENCES}

[1] Davis PH. Flora of Turkey and the East Aegean Islands. Vol. 4. Edinburgh: University of Edinburgh Press, 1975, pp. 376-531.

[2] Tuzlacı E. Türkiye Bitkileri Geleneksel İlaç Rehberi. İstanbul Tıp Kitabevleri, 2016.

[3] Diao WR, Hu QP, Zhang H, Xu JG. Chemical composition, antibacterial activity and mechanism of action of essential oil from seeds of fennel (Foeniculum vulgare Mill.). Food Control. 2014; 35(1): 109-116. [CrossRef]

[4] Rather MA, Dar BA, Sofi SN, Bhat BA, Qurishi MA. Foeniculum vulgare: A comprehensive review of its traditional use, phytochemistry, pharmacology, and safety. Arab J Chem. 2016; 9(2): 1574-1583. [CrossRef]

[5] Koşar M, Özek T, Kürkçüoglu M, Başer KHC. Comparison of microwave-assisted hydrodistillation and hydrodistillation methods for the fruit essential oils of Foeniculum vulgare. J Essent Oil Res. 2007; 19(5): 426-429. [CrossRef]

[6] Özcan MM, Chalchat JC. Chemical composition of carrot seeds (Daucus carota L.) cultivated in Turkey: Characterization of the seed oil and essential oil. Grasas Aceites. 2007; 58(4): 359-365. [CrossRef]

[7] Verma RS, Padalia RC, Chauhan A. Chemical composition variability of essential oil during ontogenesis of Daucuscarota L. subsp. sativus (Hoffm.) Arcang. Ind Crop Prod. 2014; 52: 809-814. [CrossRef]

[8] Maxia A, Marongiu B, Piras A, Porcedda S, Tuveri E, Gonçalves MJ, Salgueiro L. Chemical characterization and biological activity of essential oils from Daucus carota L. subsp. carota growing wild on the Mediterranean coast and on the Atlantic coast. Fitoterapia. 2009; 80(1): 57-61. [CrossRef]

[9] Özcan MM, Chalchat JC, Arslan D, Ateş A, Ünver A. Comparative essential oil composition and antifungal effect of bitter fennel (Foeniculum vulgare ssp. piperitum) fruit oils obtained during different vegetation. J Med Food. 2006; 9(4): 552-561. [CrossRef]

[10] Ozcan M, Akgul A. Chemical composition of the essential oil of bitter fennel (Foeniculum vulgare subsp. piperitum). J Spices Aromatic Crops. 2001; 10(1): 49-50.[CrossRef]

[11] Özcan MM, Chalchat JC. Effect of collection time on chemical composition of the essential oil of Foeniculum vulgare subsp. piperitum growing wild in Turkey. Eur Food Res Technol. 2006; 224: 279-281. [CrossRef]

[12] Stefanini MB, Ming LC, Marques MOM, Facanali R, Meireles MAA, Moura LS, Sousa LA. Essential oil constituents of different organs of fennel (Foeniculum vulgare var. vulgare). Rev Bras Plantas Med. 2006; 8: 193-198.

[13] Dadalioğlu I, Evrendilek GA. Chemical compositions and antibacterial effects of essential oils of Turkish oregano (Origanum minutiflorum), bay laurel (Laurus nobilis), Spanish lavender (Lavandula stoechas L.), and fennel (Foeniculum vulgare) on common foodborne pathogens. J Agr Food Chem. 2004; 52(26): 8255-8260. [CrossRef]

[14] Coşge B, Kiralan M, Gürbüz B. Characteristics of fatty acids and essential oil from sweet fennel (Foeniculum vulgare Mill. var. dulce) and bitter fennel fruits (F. vulgare Mill. var. vulgare) growing in Turkey. Nat Prod Res. 2008; 22(12): 1011-1016. [CrossRef]

[15] Özbek H, Ugras S, Bayram I, Uygan I, Erdogan E, Öztürk A, Huyut Z. Hepatoprotective effect of Foeniculum vulgare essential oil: A carbon-tetrachloride induced liver fibrosis model in rats. Scand J Lab Anim Sci. 2004; 31(1): 9-17. [CrossRef] 
[16] Cetin B, Özer H, Cakir A, Polat T, Dursun A, Mete E, Ekinci M. Antimicrobial activities of essential oil and hexane extract of Florence fennel [Foeniculum vulgare var. azoricum (Mill.) Thell.] against foodborne microorganisms. J Med Food. 2010; 13(1): 196-204. [CrossRef]

[17] Telci I, Demirtas I, Sahin A. Variation in plant properties and essential oil composition of sweet fennel (Foeniculumvulgare Mill.) fruits during stages of maturity. Ind Crop Prod. 2009; 30: 126-130. [CrossRef]

[18] Özbek H. The Anti-inflammatory Activity of the Foeniculum vulgare L. Essential Oil and Investigation of its Median Lethal Dosein Rats and Mice. Int J Pharmacol. 2005; 1(4): 329-331.[CrossRef]

[19] Verma RS, Padalia RC, Chauhan A. Chemical composition variability of essential oil during ontogenesis of Daucuscarota L. subsp. sativus (Hoffm.) Arcang. Ind Crop Prod. 2014; 52: 809-814. [CrossRef]

[20] Özcan MM, Chalchat JC. Chemical composition of carrot seeds (Daucus carota L.) cultivated in Turkey: characterization of the seed oil and essential oil. Grasas Aceites. 2007; 58(4): 359-365. [CrossRef]

[21] Gaglio R, Barbera M, Aleo A, Lommatzsch I, La Mantia T, Settanni L. Inhibitory activity and chemical characterization of Daucus carota subsp. maximus essential oils. Chem Biodivers. 2017; 14(5): 1-6. [CrossRef]

[22] Alves-Silva JM, Zuzarte M, Gonçalves MJ, Cavaleiro C, Cruz MT, Cardoso SM, Salgueiro L. New claims for wild carrot (Daucus carota subsp. carota) essential oil. Evid-Based Compl Alt. 2016; 1-10. [CrossRef]

[23] Bendiabdellah A, Dib MEA, Djabou N, Hassani F, Paolini J, Tabti B, Muselli A. Daucus carota ssp. hispanicus Gouan. essential oils: chemical variability and fungitoxic activity. J Essent Oil Res. 2014; 26(6): 427-440. [CrossRef]

[24] Aćimović MG, Stanković J, Cvetković M, Ignjatov M, Nikolić L. Chemical characterization of essential oil from seeds of wild and cultivated carrots from Serbia. Bot Serbica. 2016; 40(1): 55-60. [CrossRef]

[25] Kula J, Izydorczyk K, Czajkowska A, Bonikowski R. Chemical composition of carrot umbel oils from Daucus carota L. ssp. sativus cultivated in Poland. Flavour Frag J. 2006; 21(4): 667-669. [CrossRef]

[26] Chizzola R. Composition of the essential oil from Daucus carota ssp. carota growing wild in Vienna. J Essent Oil Bear Pl. 2010; 13(1): 12-19. [CrossRef]

[27] Mojab F, Hamedi A, Nickavar B, Javidnia K. Hydrodistilled volatile constituents of the leaves of Daucus carota L. subsp. sativus (Hoffman.) Arcang. (Apiaceae) from Iran. J Essent Oil Bear Pl. 2008; 11(3): 271-277. [CrossRef]

[28] Meliani N, Dib A, Bendiabdellah A, Djabou N, Chikhi I, Allali H, Tabti B. Evaluation of antioxidant activity of essential oil and extracts from Algerian Daucus carota L. aerial parts. Global J Pharm Res. 2012; 1(5): 1121-1129.

[29] Saad HA, El-Sharkawy SH, Halim AF. Essential oils of Daucus carota ssp. maximus. Pharm Acta Helv. $1995 ;$ 70: 79-84. [CrossRef]

[30] Flamini G, Cosimi E, Cioni PL, Molfetta I, Braca A. Essential-oil composition of Daucus carota ssp. major (Pastinocello Carrot) and nine different commercial varieties of Daucus carota ssp. sativus fruits. Chem Biodivers. 2014; 11: 10221033. [CrossRef]

[31] Imamu X, Yili A, Aisa HA, Maksimov VV, Veshkurova ON, Salikhov SI. Chemical composition and antimicrobial activity of essential oil from Daucus carota sativa seeds. Chem Nat Compd. 2007; 43(4): 495-496. [CrossRef]

[32] Gonny M, Bradesi P, Casanova J. Identification of the components of the essential oil from wild Corsican Daucus carota L. using ${ }^{13}$ C-NMR spectroscopy. Flavour Frag J. 2004; 19(5): 424-433. [CrossRef]

[33] Rossi PG, Berti L, Panighi J, Luciani A, Maury J, Muselli A, Bolla JM. Antibacterial action of essential oils from Corsica. J Essent Oil Res. 2007; 19(2): 176-182. [CrossRef]

[34] Maxia A, Marongiu B, Piras A, Porcedda S, Tuveri E, Gonçalves MJ, Salgueiro L. Chemical characterization and biological activity of essential oils from Daucus carota L. subsp. carota growing wild on the Mediterranean coast and on the Atlantic coast. Fitoterapia. 2009; 80(1): 57-61. [CrossRef]

[35] Brochot A, Guilbot A, Haddioui L, Roques C. Antibacterial, antifungal, and antiviral effects of three essential oil blends. MicrobiologyOpen. 2017; 6(4): e00459. [CrossRef]

[36] Mockute D, Nivinskiene O. The sabinene chemotype of essential oil of seeds of Daucus carota L. ssp. carota growing wild in Lithuania. J Essent Oil Res. 2004; 16(4): 277-281. [CrossRef]

[37] Mohammedi H, Mecherara-Idjeri S, Foudil-Cherif $Y$, Hassani A. Chemical composition and antioxidant activity of essential oils from Algerian Daucus carota L. subsp. carota aerial parts. J Essent Oil Bear Pl. 2015; 18(4): 873-883. [CrossRef]

[38] Pinilla MG, Pérez-Alonso MJ, Velasco-Negueruela A. Volatile constituents from fruits of Daucus carota L., subsp. gummifer Hooker Fil. J Essent Oil Res. 1995; 7(4): 433-435. [CrossRef] 
[39] Rossi PG, Bao L, Luciani A, Panighi J, Desjobert JM, Costa J, Berti L. (E)-Methylisoeugenol and elemicin: Antibacterial components of Daucus carota L. essential oil against Campylobacter jejuni. J Agr Food Chem. 2007; 55(18): $7332-7336$. [CrossRef]

[40] Smigielski KB, Majewska M, Kunicka-Styczyñska A, Gruska R. The effect of ultrasound-assisted maceration on the bioactivity, chemical composition and yield of essential oil from waste carrot seeds (Daucus carota). J Essent Oil Bear Pl. 2014; 17(6): 1075-1086. [CrossRef]

[41] Staniszewska M, Kula J. Composition of the essential oil from wild carrot umbels (Daucus carota L. ssp. carota) growing in Poland. J Essent Oil Res. 2001; 13(6): 439-441. [CrossRef]

[42] Staniszewska M, Kula J, Wieczorkiewicz M, Kusewicz D. Essential oils of wild and cultivated carrots-the chemical composition and antimicrobial activity. J Essent Oil Res. 2005; 17(5): 579-583. [CrossRef]

[43] Glišić SB, Mišić DR, Stamenić MD, Zizovic IT, Ašanin RM, Skala DU. Supercritical carbon dioxide extraction of carrot fruit essential oil: Chemical composition and antimicrobial activity. Food Chem. 2007; 105(1): 346-352. [CrossRef]

[44] Rokbeni N, M'rabet Y, Dziri S, Chaabane H, Jemli M, Fernandez X, Boulila A. Variation of the chemical composition and antimicrobial activity of the essential oils of natural populations of Tunisian Daucus carota L. (Apiaceae). Chem Biodivers. 2013; 10(12): 2278-2290. [CrossRef]

[45] Tavares AC, Gonçalves MJ, Cavaleiro C, Cruz MT, Lopes MC, Canhoto J, Salgueiro LR. Essential oil of Daucus carota subsp. halophilus: composition, antifungal activity and cytotoxicity. J Ethnopharmacol. 2008; 119(1): 129-134. [CrossRef]

[46] Jabrane A, Jannet HB, Harzallah-Skhiri F, Mastouri M, Casanova J, Mighri Z. Flower and Root Oils of the Tunisian Daucus carota L. ssp. maritimus (Apiaceae): Integrated Analyses by GC, GC/MS, and 13C-NMR Spectroscopy, and in vitro Antibacterial Activity. Chem Biodivers. 2009; 6(6): 881-889. [CrossRef]

[47] Asilbekova DT, Bobakulov KhM, Sasmakov, SA, Abdurakhmanov JM, Azimova ShS, Abdullaev ND, Sagdullaev Sh. Composition and antimicrobial activity of essential oils from Daucus carota L. subsp. carota, growing in Uzbekistan. Am J Essent OilNat Prod. 2017; 5(4): 9-13.[CrossRef]

[48] Chauhan RS, Kitchlu S, Ram G, Kaul MK, Tava A. Chemical composition of capillene chemotype of Artemisia dracunculus L. from North-West Himalaya, India. Ind Crop Prod. 2010; 31(3): 546-549. [CrossRef]

[49] Gulfraz M, Mehmood S, Minhas N, Jabeen N, Kausar R, Jabeen K, Arshad G. Composition and antimicrobial properties of essential oil of Foeniculum vulgare. Afr J Biotechnol. 2008; 7(24): 4364-4368.[CrossRef]

[50] Anwar F, Ali M, Hussain AI, Shahid M. Antioxidant and antimicrobial activities of essential oil and extracts of fennel (Foeniculum vulgare Mill.) seeds from Pakistan. Flavour Frag J. 2009; 24(4): 170-176. [CrossRef]

[51] Roby MHH, Sarhan MA, Selim KAH, Khalel KI. Antioxidant and antimicrobial activities of essential oil and extracts of fennel (Foeniculum vulgare L.) and chamomile (Matricaria chamomilla L.). Ind Crop Prod. 2013; 44: 437-445. [CrossRef]

[52] Dadalioğlu I, Evrendilek GA. Chemical compositions and antibacterial effects of essential oils of Turkish oregano (Origanum minutiflorum), bay laurel (Laurus nobilis), Spanish lavender (Lavandula stoechas L.), and fennel (Foeniculum vulgare) on common foodborne pathogens. J Agr Food Chem. 2004; 52(26): 8255-8260. [CrossRef]

[53] Mota AS, Martins MR, Arantes S, Lopes VR, Bettencourt E, Pombal S, Silva LA. Antimicrobial activity and chemical composition of the essential oils of Portuguese Foeniculum vulgare fruits. Nat Prod Commun. 2015; 10(4): 673-676. [CrossRef]

[54] Mohammedi H, Mecherara-Idjeri S, Foudil-Cherif Y, Hassani A. Chemical composition and antioxidant activity of essential oils from Algerian Daucus carota L. subsp. carota aerial parts. J Essent Oil Bear Pl. 2015; 18(4): 873-883. [CrossRef]

[55] Felice S, Oliviero F, Scandolera E, Taglialatela-Scafati O, Roscigno G, Zaccardelli M, De Falco E. Chemical composition, antimicrobial and antioxidant activities of anethole-rich oil from leaves of selected varieties of fennel [Foeniculum vulgare Mill. ssp. vulgare var. azoricum (Mill.) Thell]. Fitoterapia. 2013; 90: 214-219. [CrossRef]

[56] Miguel MG, Cruz C, Faleiro L, Simões MTF, Figueiredo AC, Barroso JG, Pedro LG. Foeniculum vulgare essential oils: Chemical composition, antioxidant and antimicrobial activities. Nat Prod Commun. 2010; 5(2): 319-328. [CrossRef]

[57] Albano SM., Lima AS, Miguel MG, Pedro LG., Barroso JG, Figueiredo AC. Antioxidant, anti-5-lipoxygenase and antiacetylcholinesterase activities of essential oils and decoction waters of some aromatic plants. Rec Nat Prod. 2012; 6(1): 35-48. [CrossRef] 
[58] Silva JMA. Master Thesis. Study of bioactive properties of Daucus carota subsp. carota extracts and essential oil. Faculty of Pharmacy, University of Coimbra, Portugal, 2015. [CrossRef]

[59] Frum Y, Viljoen AM. In vitro 5-lipoxygenase activity of three indigenous South African aromatic plants used in traditional healing and the stereospecific activity of limonene in the 5-lipoxygenase assay. J Essent Oil Res. 2006; 18(1): 85-88. [CrossRef]

[60] Rufino AT, Ribeiro M, Judas F, Salgueiro L, Lopes MC, Cavaleiro C, Mendes AF. Anti-inflammatory and chondroprotective activity of (+)- $\alpha$-pinene: Structural and enantiomeric selectivity. J Nat Prod. 2014; 77(2): $264-269$. [CrossRef]

[61] Wu Q-f, Wang W, Dai X-y, Wang Z-y, Shen Z-h, Ying H-z, Yu C-h. Chemical compositions and anti-influenza activities of essential oils from Mosla dianthera. J Ethnopharmacol. 2012; 139(2): 668-671. [CrossRef]

[62] Rodrigues LB, Martins AOBPB, Cesário FRAS, Castro FF, Albuquerque TRde, Fernandes MNM, Silva BAFda, Júnior LJQ, Costa JGMda, Coutinho HDM, Barbosa R, Menezesa IRAde. Anti-inflammatory and antiedematogenic activity of the Ocimum basilicum essential oil and its main compound estragole: In vivo mouse models. Chem-Biol Interact. 2016; 257: 14-25. [CrossRef]

[63] Rao R, Reedy S. Hypoglycaemic and antidiabetic activity of Daucus carota seeds in alloxan induced diabetic rats. Pharmanest. 2013; 4(5): 907-913.

[64] El-Soud NA, El-Laithy N, El-Saeed G, Wahby MS, Khalil M, Morsy F, Shaffie N. Antidiabetic activities of Foeniculumvulgare Mill. essential oil in streptozotocin-induced diabetic rats. Macedonian J Med Sci. 2011; 4(2): 139146. [CrossRef]

[65] Murali R, Saravanan R. Antidiabetic effect of d-limonene, a monoterpene in streptozotocin-induced diabetic rats. Biomed Prev Nutr. 2012; 2(4): 269-275. [CrossRef]

[66] Servi H, Sen A, Dogan A. Chemical composition and biological activities of endemic Tripleurospermum conoclinium (Boiss. \& Balansa) Hayek essential oils. Flavour Frag J. 2020; 35(6): 713-721. [CrossRef]

[67] İşcan G, Kirimer N, Kürkcüoğlu M, Başer HC, Demirci F. Antimicrobial screening of Mentha piperita essential oils. J Agr Food Chem. 2002; 50(14): 3943-3946. [CrossRef]

[68] Zou Y, Chang SK, Gu Y. Qian SY. Antioxidant activity and phenolic compositions of lentil (Lens culinaris var. morton) extract and its fractions. J Agr Food Chem. 2011; 59(6): 2268-2276. [CrossRef]

[69] Phosrithong N, Nuchtavorn N. Antioxidant and anti-inflammatory activites of Clerodendrum leaf extracts collected in Thailand. Eur J Integr Med. 2016; 8(3): 281-285. [CrossRef]

[70] Yıldırım A, Şen A, Doğan A, Bitis L. Antioxidant and anti-inflammatory activity of capitula, leaf and stem extracts of Tanacetum cilicicum (Boiss.) Grierson. Int J Secondary Metabolite. 2019; 6(2): 211-222. [CrossRef]

[71] Ramakrishna R, Sarkar D, Schwarz P. Shetty K. Phenolic linked anti-hyperglycemic bioactives of barley (Hordeum vulgare L.) cultivars as nutraceuticals targeting type 2 diabetes. Ind Crop Prod. 2017; 107: 509-517. [CrossRef]

[72] Sen A, Kurkcuoglu M, Senkardes I, Bitis L, Baser KHC. Chemical composition, antidiabetic, anti-inflammatory and antioxidant activity of Inula ensifolia L. essential oil. J Essential Oil Bear Pl. 2019; 22(4): 1048-1057. [CrossRef] 